\title{
PROTOTIPE BUAH DALAM PERSPEKTIF MASYARAKAT INDONESIA: KAJIAN BAHASA, KOGNISI, DAN BUDAYA
}

\author{
Ibnu Eko Setiawan, M.A. \\ SMA Negeri 3 Sungai Lilin \\ Bimbingan Belajar "Rumah Guru" \\ Pos-el: ibnuekosetiawan@yahoo.com
}

\begin{abstract}
Abstrak
Bahasa adalah bagian dari budaya, dari bahasa dapat tergambar budaya manusia. Bahasa juga menggambarkan cara pikir dari manusia. Melalui bahasa, dapat dilihat pengkategorian kata. Penelitian ini menemukan pandangan masyarakat Indonesia mengenai kata buah. Penelitian menggunakan kuantitatif dengan pertanyaan dan lembar kerja sebagai instrumennya. Temuan penelitian menunjukkan bahwa masyarakat Indonesia memilih apel dan jeruk sebagai prototipe kata 'buah'
\end{abstract}

Kata kunci: prototipe, linguistik kognitif, bahasa, budaya

\section{FRUIT PROTOTYPE IN INDONESIA PERSPECTIVES: STUDY OF LANGUAGES, COGNITION, AND CULTURE}

\begin{abstract}
Language is a part of culture, so that it culture can be reflected in the language. Language is transmitted through the ages and language reflects what a person thinks. Through the language, it can be seen on how a culture perceives a word and makes its categorization. This research would like to find out about Indonesian's point of view about the word 'fruit'. It is a descriptive quantitative research which uses questionnaires and worksheet as the instruments of the research. The findings of the research show that Indonesian chooses apple and orange as the prototype of fruits. The research is also trying to find out the characteristics of the prototype 'fruits'.
\end{abstract}

Keywords : prototype, cognitive linguistics, language, culture

\section{PENDAHULUAN}

Bahasa adalah bagian dari kebudayaan atau dengan kata lain kebudayaan dapat terefleksi ke dalam bahasa. Bahasa ditransmisikan secara turun temurun, dan bahasa merefleksikan apa yang mencari pemikiran atau pola pikir seseorang. Kognisi manusia memiliki kebudayaan di dalamnya dan bahasa digunakan untuk menjaga atau mempertahankan kebudayaannya. Kognisi manusia berhubungan dengan ide yang berhubungan 
dengan objek, baik objek yang nyata maupun objek yang bersifat abstrak Dapat ditarik sebuah simpulan mengenai hubungan bahasa, kognisi dan budaya adalah bahasa merupakan pembentuk kognisi. Seseorang mempunyai pengalaman hidup dengan objek atau banyak hal yang dia lihat, dengar, dan rasakan. Pengalaman tersebutlah yang diolah oleh otak sehingga otak mampu memisahkan pengalamanpengalaman tersebut berdasarkan kategori-kateori tertentu. Dapat disimpulkan bahwa kognisi adalah kepercayaan seseorang tentang sesuatu yang didapatkan dari proses berpikir tentang seseorang atau sesuatu. Menurut Bruce Berger, serangkaian proses yang dilakukan dalam berpikir adalah memperoleh pengetahuan dan memanipulasi pengetahuan melalui aktivitas mengingat, menganalisis, memahami, menilai, menalar, membayangkan dan berbahasa. Kognisi dapat pula diartikan sebagai pemahaman terhadap pengetahuan atau kemampuan untuk memperoleh pengetahuan. Istilah ini digunakan oleh filsuf untuk mencari pemahaman terhadap cara manusia berpikir (Stemberg, 2006). Kapasitas atau kemampuan kognisi biasa diartikan sebagai kecerdasan atau inteligensi.

Dalam berbagai macam penggunaan, bahasa berinteraksi dengan nilai-nilai sosial sehingga bahasa banyak berhubungan dengan nilai sosial dan kebudayaan yang hidup dalam masyarakat bahasa tersebut. Bahasa dan kebudayaan mempunyai hubungan yang timbal balik, begitu juga dengan pola pikir atau kognisi. Hubungan timbal balik ini mempengaruhi dalam berbagai tingkat. Sebuah pandangan klasik berpendapat bahwa bagaimana hubungan bahasa dengan kebudayaan adalah pandangan yang menganggap bahwa struktur bahasa, berdasarkan konsep dan kategori kebudayaan yang terpadu dalam bahasa, menentukan cara penuturnya berpikir, melihat dunia, dan menetukan perilakunya. Pandangan satu arah semacam ini dinamakan pandangan deterministik, relativitas linguistik, atau yang lebih dikenal lagi dengan hipotesis Sapir-Whorf (Wierzbicka, 1992). Pandangan ini disebut relativitas linguistik karena 
beranggapan bahwa bahasa

Perbedaan lokasi dan kondisi

membentuk kebudayaan

Melalui bahasa dapat dilihat bagaimana sebuah budaya memandang sebuah kata dan membuat pengkategoriannya. 'Buah' adalah sebuah konsep tentang objek yang dipandang sederhana. Penelitian tentang konsep 'fruits' atau 'buah' dalam bahasa Inggris telah dijalankan, dan hasil yang ditemukan adalah 'red apple' atau buah apel merahlah yang menjadi prototipe kata tersebut (Smith, 1988). Mengingat penelitian tersebut diadakan di Eropa, dimana daerah tersebut merupakan daerah empat musim yang memiliki keragaman vegetasi fauna yang terbatas, maka penelitian tentang bagaimana cara pandang masyarakat penutur bahasa Indonesia memandang kata 'buah' adalah menjadi topik yang cukup menarik untuk diperbincangkan. Hal ini dikarenakan Indonesia yang terletak di garis Khatulistiwa dan memiliki iklim tropis dengan gunung-gunung api yang aktif menyebabkan daerah ini menjadi daratan yang subur dan memiliki keragaman hayati, khususnya buahbuahan. penelitian, serta keragaman objek penelitian, adalah pembeda yang utama penelitian-penelitian ini dengan penelitian sebelumnya. Melalui penelitian ini maka akan terlihat bagaimana prototipe 'buah' dalam kognisi masyarakat Indonesia.

'Buah' merupakan salah satu bahan pangan yang dapat dikatakan sebagai bahan makanan penting bagi kehidupan manusia. Di Indonesia, beragam jenis buah dapat dengan mudahnya untuk ditemui. Buah biasanya disantap sebagai hidangan penutup dan biasanya tidak disantap setelah melalui proses memasak terlebih dahulu.

Secara wujudnya, menurut Lewis (2002), buah adalah bagian tanaman yang merupakan proses kelanjutan dari bakal buah yang terdapat pada bunga. Buah biasanya membungkus biji. Sedangkan menurut Tjitrosoepomo (1986), buah merupakan bagian dari tumbuhan, diaman di dalam buah terdapat biji. Pengertian diatas adalah pengertian buah dengan sudut pandang biologi, dan ketika kata 'buah' dihubungkan dengan pandangan masyarakat, penulis berasumsi bahwa yang 
dimaksud dengan buah memiliki makna yang lebih meluas dari sekedar bagian dari tanaman dan merupakan proses kelanjutan perkembangan dari bunga. Penulis membuat hipotesis awal bahwa buah dapat pula berasal dari perkembangan organ yang lain. Dengan hipotesis awal ini dan pengamatan sekilasa dalam masyarakat, batasan 'buah' menjadi lebih longgar dari sekedar definisi dalam ilmu biologi atau ilmu botani. Istilah 'buah-buahan' dapat digunakan untuk pengertian demikian. Hipotesis awal penulis adalah 'buah' atau 'buah-buahan' merupakan setiap bagian tumbuhan di permukaan tanah yang tumbuh membesar dan (biasanya) berdaging atau banyak mengandung air.
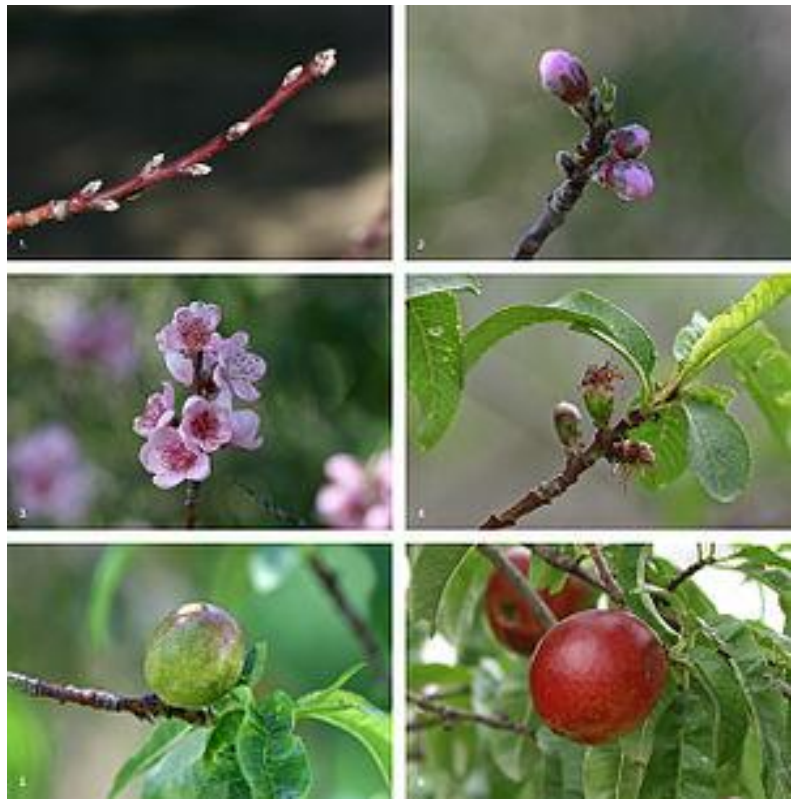

\section{Gambar 1 Proses Pembentukan}

Buah METODE PENELITIAN

Penelian ini menggunakan metode deskriptif kuantitatif. Instrumen yang dipakai dalam penelitian ini terbagi menjadi tiga, yaitu:

1. semacam lembar kerja yang di dalam terdapat intruksi untuk menggambar 'buah'.

2. semacam daftar isian yang meminta responden untuk menuliskan sepuluh jenis buah.

3. semacam angket yang berisi skala penilaian terhadap bagaimana responden menilai sesuatu dan memutuskan apakah itu tergolong sebagai buah atau bukan. Dengan diberlakukannya tiga tahapan 
penelitian, berarti penelitian ini dilakukan dengan berapa tahapan.

Tahapan awal yang dilakukan sebelum memulai penelitian ini adalah dengan mengumpulkan definisi 'buah' dari bermacam sudut pandang, seperti kamus, internet dan pandangan mereka tentang konsep 'buah' yang ada di pikiran mereka. Setelah tahapan brainstorming, penulis mencoba untuk menemukan variabel yang selanjutnya dijadikan dasart untuk penyusunan angket untuk menjelaskan makna kata 'buah'.

Lembar kerja penelitian meliputi lembar pertama yaitu semacam kertas dengan ruang kosong untuk menggambar. Lembar kerja ini selanjutnya disebut dengan Lembar Penelitian I (LP1). LP1 ini bertujuan untuk memantapkan variabel yang telah disusun oleh penulis. Melalui LP1, penulis dapat melihat secara visual tentang apa yang dipikirkan oleh responden mengenai 'buah".

Setelah LP1 disebarkan, penulis melanjutkan penelitian dengan memberikan semacam daftar kosong yang harus diisi dengan sepuluh nama buah. Tahapan ini selanjutnya disebut dengan Lembar Penelitian 2 atau LP2. Penyebaran LP2 bertujuan untuk menentukan hipotesis dasar mengenai buah yang populer di Indonesia dan konsep pemikiran responden mengenai 'buah'.

Setelah LP1 dan LP2 disebarkan dan hasil penelitian sementara telah diperoleh, penulis mencoba menyusun sebuah angket yang berisikan empat puluh nama buah yang di dalamnya terdapat variabel. Susunan variabel terhadap nama-nama buah tersebut disusun secara acak, sehingga buah dengan kelompok variabel yang sama tidak berada saling berdekatan. Ini dilakukan agar responden lebih teliti dan melakukan pengisisan angket dengan serius. Angket disusun dengan memberikan skala 1-5. Konsep perhitungannya adalah semakin besar angka yang diberikan terhadap buah jenis tertentu berarti semakin besar pulalah asumsi responden yang menganggap hal tersebut sebagai 'buah'.

Berdasarkan langkah-langkah kerja dari LP1, LP2, dan LP3, maka langkah kerja tersebut akan dibawa ke dalam sebuah proses yang 


\begin{abstract}
dinamakan perumusan hipotesis dengan penentuan variabel. Perumusan hipotesis mengenai 'buah' dalam sudut pandang masyarakat Indonesia adalah dengan mencoba memikirkan buah apa yang pertama kali terlintas dalam pikiran penulis dan kemudian mencoba mencari variabel-variabel yang tepat untuk meneruskan penelitian ini. Penulis memikirkan bahwa buah yang pertama kali terlintas dalam pikiran adalah jeruk dan apel.
\end{abstract}

Penelitian ini seperti mengungkap cara pikir seseorang memandang buah. Seperti ilustrasi berikut, ketika seseorang melihat burung terbang di angkasa, dia tidak akan memikirkan sebuah konsep atrifisial yaitu burung merupakan hewan berdarah panas yang dapat terbang, mempunyai sayap, dan bertelur. Hal yang menjadi pemikiran manusia tentang burung lebih kepada manusia yang menggunakan konsep alamiahnya atau pengalaman berpikirnya yang membawanya kepada kerangka konsep alami yang disebut prototipe. Kebanyakan orang sudah mempunyai prototipe burung sehingga pada akhirnya ia mampu membedakan mana yang burung dan mana yang bukan burung. Ketika kita telah menemukan contoh kasus yang bukan merupakan bentuk dari prototipe yang biasanya, maka kita baru meninjaunya dengan konsep artifisial yang ada pada diri seseorang. Contoh kasusnya adalah ketika seseorang melihat pinguin dan mengetahi bahwa pinguin tidak dapat terbang, maka ia akan kesulitan yang lebih untuk mengklasifikasikannya sebagai burung atau bukan. Disinilah konsep artifisial muncul.

$$
\begin{aligned}
& \text { Melalui konsep pemikiran } \\
& \text { seperti bagaimana merumuskan } \\
& \text { prototipe burung, penulis mencoba } \\
& \text { membuat beberapa variabel yang } \\
& \text { berkaitan dengan buah dan variabel- } \\
& \text { variabel ini diharapkan dapat } \\
& \text { memberikan peta konsep yang jelas } \\
& \text { mengenai cara pandang masyarakat } \\
& \text { Indonesia terhadap 'buah'. Variabel } \\
& \text { tersebut antara lain: }
\end{aligned}
$$

1. Bentuk (Buah cenderung berbentuk bulat)

2. Warna (Berwarna cerah, seperti merah, kuning, atau hijau)

3. Daging buah berair dengan rasa manis

4. Dimakan tanpa melalui pengolahan atau pemasakan lebih lanjut

5. Berasal dari bunga.

Distribusi variabel penelitian mengikuti konsep pada tabel berikut. 
Variabel:

1. Bentuk buah cenderung bulat

2. Berwarna cerah

3. daging buah berair dan manis

4. dimakan tanpa melalui pemasakan.

5. berasal dari bunga.

Variabel:

2

2. Berwarna cerah

3. daging buah berair dan manis

4. dimakan tanpa melalui pemasakan.

5. berasal dari bunga.

Variabel:

1. Bentuk buah cenderung bulat

3. daging buah berair dan manis

4. dimakan tanpa melalui pemasakan.

5. berasal dari bunga.

Variabel:

1. Bentuk buah cenderung bulat

2. Berwarna cerah

3. daging buah berair dan manis

5. berasal dari bunga.

Variabel:

2. Berwarna cerah

3. daging buah berair dan manis

4. dimakan tanpa melalui pemasakan.

Variabel:

6

1. Bentuk cenderung bulat

2. Berwarna cerah

4. dimakan tanpa melalui pemasakan.

Variabel:

7

2. Berwarna cerah

3. daging buah berair dan manis

5. berasal dari bunga.

Variabel: $\quad 8$

1. Bentuk buah cenderung bulat

2. Berwarna cerah

5. berasal dari bunga.

Variabel:

2. Berwarna cerah

4. dimakan tanpa melalui pemasakan.

5. berasal dari bunga.

Variabel:

10

2. Berwarna cerah

5. berasal dari bunga.

Variabel:

11

3. daging buah berair dan manis

$$
\text { Pada penyusunan LP3, }
$$

ternyata pengeleminasian empat variabel sehingga menyisakan satu variabel saja ternyata tidak bisa dilakukan karena jika menyisakan satu variabel saja maka itu sudah sangat mencerminkan 'bukan buah' dan sangat sulit untuk menemukan sebuah kondisi dalam kehidupan nyata 'buah' dengan satu variabel saja. Menurut penulis, dengan pengeliminasian satu per satu variabel (maksimal sampai tiga variabel saja) itu sudah cukup untuk menarik kesimpulan akhir.

Setelah peneliti membuat LP1, LP2, dan LP3, penulis menyebarkan LP tersebut dengan jumlah responden tiap tahapan berbeda-beda. Ini dilakukan karena penurut penulis, tingkat penentuan dari tiap-tiap LP berbeda satu sama lain, terdapat LP yang dengan jumlah responden sedikit namun kesimpulan dapat ditarik, namun ada juga yang mengalami kasus sebaliknya. LP1 disebarkan kepada lima responden dari berbagai kalangan. LP2 disebarkan kepada sepuluh responden dari kalangan berbeda, sementara LP3 disebarkan kepada dua puluh orang responden. Pada LP3, responden diminta untuk memberikan penilaian mulai dari 
angka 1- 5 untuk sesuatu yang mereka yakini itu buah atau bukan (angket terlampir).

Analisis data dilakukan setelah angket terkumpul. Analisis menggunakan perhitungan statistik sederhana untuk mengetahui jumlah jawaban responden terhadap pertanyaan/cerita tersebut. Penyajian data dilakukan formal dan informal. Penyajian data formal dilakukan dalam bentuk tabel hasil penelitian dan penyajian data informal dilakukan dengan kata-kata yang mudah dipahami.

\section{HASIL DAN PEMBAHASAN}

\section{Lembar Penelitian 1}

Lembar Penelitian 1 atau LP1 disebarkan kepada lima orang responden. Hal yang harus dilakukan responden adalah menggambar satu macam buah yang mereka ketahui dan terlintas pertama kali di pikiran mereka. Untuk memperoleh relaibilitas dari penelitian ini, LP1 disebarkan kepada lima responden dengan latar belakang umur, pekerjaan, dan suku. Anak-anak juga dijadikan sebagai salah satu dari lima responden. Dua orang anak-anak dinilai dapat mewakili apa yang anak-anak pikirkan mengenai buah.

Dari hasil yang digambarkan oleh para responden, kelima responden tersebut menggambarkan buah yang beragam, yaitu apel, jeruk (dua orang responden menggambar buah ini), mangga, dan kelapa. Berdasarkan dari apa yang telah digambarkan oleh responden, peneliti menarik variabel untuk meneruskan ke penelitian selanjutnya bahwa yang disebut sebagai 'buah' adalah bagian dari tumbuhan yang berbentuk bulat, memiliki kulit berwarna teramg atau cerah, dan memiliki rasa daging buah yang manis dan berair.

Melalui LP1 ini dapat dilihat bahwa aspek umum dari prototipe yang dihadirkan adalah buah-buah dengan tipe-tipe seperti mangga, apel, dan jeruk, sementara kelapa terlihat tidak satu kelompok karena ukurannya yang jauh berbeda dengan tiga buah sebelumya. Istilah prototipe sendiri terkadang digunakan untuk melihat sebuah representasi dari contoh terbaik dari sebuah konsep (e.g., Medin \& Schaffer, 1978; Mervis \& Rosch, 1981). Pada kasus ini, yang menjadi contoh terbaik adalah jeruk. 


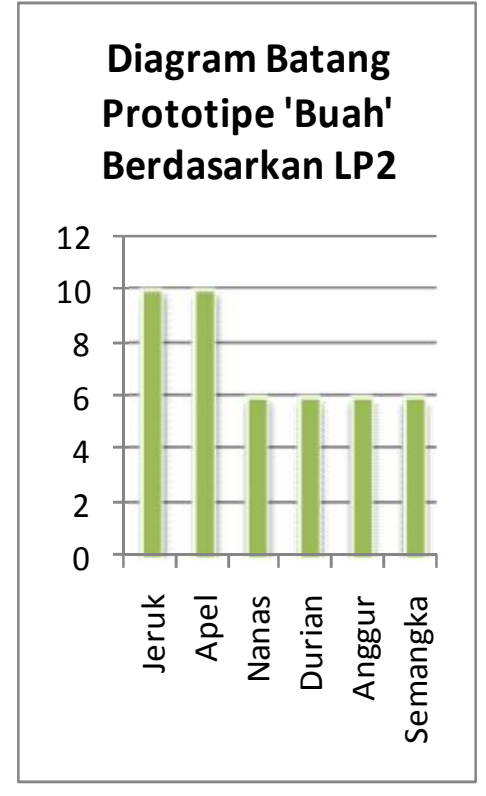

\section{Lembar Penelitian 2}

Hasil yang diharapkan oleh penulis pada lembar penelitian 2 adalah responden menyebutkan sepuluh macam buah sehingga penulis dapat melihat buah apa yang paling banyak disebut dan jenis buah apa yang tidak banyak disebut oleh responden. Buah yang paling banyak disebut dapat dijadikan sebagai indikator bahwa buah tersebut merupakan sebuah contoh yang baik dari macam-macam buah yang ada.

\section{LP2 disebarkan kepada} sepuluh responden dengan rentang usia yang berbeda-beda, pekerjaan yang berbeda-beda (guru, mahasiswa, dosen, dan ibu rumah tangga), dan latar belakang yang berbeda-beda pula (Jawa, Minang, Melayu, Betawi, dan Dayak).
Berdasarkan hasil yang diperoleh dari LP2, penulis menyusun 'buah' yang dipilih oleh lima atau lebih dari lima responden untuk dituliskan ke dalam diagram batang. Melalui diagram batang inilah dapat dilihat buah-buah apa sajakah yang termasuk prototipe atau contoh buah yang baik.

\section{Berdasarkan hasil yang} diperoleh dari LP2, diagram batang di atas menunjukkan bahwa terdapat dua macam buah yang menjadi contoh prototipe buah yang baik menurut responden yang merupakan masyarakat penutur bahasa Indonesia.

\section{Lembar Penelitian 3}

Berdasarkan hasil penelitian secara botani, buah sejati (dalam pengertian ilmu botani) terkadang tidak disebut sebagai 'buah' dalam masyarakat bahasa Indonesia. Menurut ilmu botani, buah yang merupakan hasil perkembangan dari bakal buah yang berasal dari bunga. Namun, hasil penelitian ini menunjukkan bahwa banyak buah dalam definisi botani dianggap bukan buah dalam sudut pandang atau perspektif masyarakat, misalnya buah tomat, buah cabai, polong 
kacang panjang, dan buah ketimun. 'Buah' tersebut dipandang sebagai bukan buah melainkan sayursayuran. Ini menunjukkan bahwa masyarakat tidak hanya memandang bagaimana buah dihasilkan, tapi juga melibatkan aspek lain yaitu fungsi buah dalam masyarakat..

Pada di atas, terlihat bahwa ketika semua variabel dimasukkan, buah dengan kategori ini memiliki nilai yang tinggi. Namun, hanya markisa yang menunjukkan nilai yang rendah. Ini diasumsikan karena walaupun markisa berair dan manis, namun markisa memiliki tekstur daging buah yang berlendir, sehingga membedakannya dengan buah jenis lain. Oleh karena itu, dalam penelitian lanjutan diasumsikan bahwa 'tekstur daging buah'diperlukan sebagai tambahan variabel.

\begin{tabular}{|c|c|c|}
\hline $\begin{array}{l}\text { Nomor Kategori Per } \\
\text { Variabel }\end{array}$ & Nama Buah & $\begin{array}{l}\text { Jum } \\
\text { lah }\end{array}$ \\
\hline Kategori 2 & $\begin{array}{ll}1 . & \text { Pisang } \\
\text { Ambon } & \\
\end{array}$ & 98 \\
\hline \multirow{4}{*}{$\begin{array}{l}\text { Variabel: } \\
\text { 2. Berwarna cerah } \\
\text { 3. daging buah } \\
\text { berair dan manis } \\
\text { 4. dimakan tanpa } \\
\text { melalui pemasakan. } \\
5 . \text { berasal dari } \\
\text { bunga. }\end{array}$} & 2. Belimbing & 89 \\
\hline & 3. Nanas & 95 \\
\hline & 4. Durian & 90 \\
\hline & & \\
\hline \multicolumn{2}{|l|}{ Jumlah total } & 372 \\
\hline \multicolumn{2}{|c|}{ Rata-rata per kategori $(372: 4)$} & 93 \\
\hline
\end{tabular}

\begin{tabular}{|c|c|c|}
\hline Kategori 3 & 1. Sawo & 95 \\
\hline \multirow{4}{*}{$\begin{array}{l}\text { Variabel: } \\
\text { 1. Bentuk buah } \\
\text { cenderung bulat } \\
\text { 3. daging buah } \\
\text { berair dan manis } \\
\text { 4. dimakan tanpa } \\
\text { melalui pemasakan. } \\
\text { 5. berasal dari } \\
\text { bunga. }\end{array}$} & 2. Salak & 94 \\
\hline & 3. Kelengkeng & 98 \\
\hline & 4. Manggis & 100 \\
\hline & & \\
\hline \multicolumn{2}{|l|}{ Jumlah total } & 387 \\
\hline \multicolumn{2}{|c|}{ Rata-rata per kategori (387:4) } & 96,7 \\
\hline
\end{tabular}

Berdasarkan hasil dari kagtegori 2 dan 3, terlihat ketika salah satu variabel yaitu bentuk buah atau warna buah dihilangkan, hasil tetap menunjukkan angka yang tinggi. Ini menunjukkan bahwa keduanya merupakan variabel penting namun tidak begitu berpengaruh ketika dihilangkan asalkan salah satu dari kedua data tersebut tetap dipertahankan.

Hal berbeda terjadi ketika variabel 'dimasak tanpa melalui proses pemasakan' dihilangkan. Variabel ini memiliki peranan sangat penting karena ketika variabel ini dihilangkan, tingkat ke'buah'an menjadi rendah. Ini menunjukkan bahwa masyarakat Indonesia menilai ‘buah' dengan bagaimana buah disantap atau dinikmati, juga melibatkan faktor lain yaitu faktor fungsi, seperti keterlibatan 'buah' sebagai sayur. Sehingga dalam kasus 
semacam ini, buah sering disebut sebagai sayur. Kolang-kaling diasumsikan memiliki nilai yang rendah karena keberadaannya dianggap sebagai pelengkap minuman, bukan sebagai buah yang disantap tanpa campuran bahan lain. Kopi dalam kategori ini juga lebih dianggap sebagai minuman.

\begin{tabular}{|c|c|c|}
\hline $\begin{array}{ll}\begin{array}{l}\text { Nomor Kategori Per } \\
\text { Variabel }\end{array} & \end{array}$ & Nama Buah & $\begin{array}{l}\text { Juml } \\
\text { ah }\end{array}$ \\
\hline Kategori 4 & 1. Tomat & 62 \\
\hline \multirow{4}{*}{$\begin{array}{l}\text { Variabel: } \\
\text { 1. Bentuk buah } \\
\text { cenderung bulat } \\
\text { 2. Berwarna cerah } \\
\text { 3. daging buah berair } \\
\text { dan manis } \\
\text { 5. berasal dari bunga. }\end{array}$} & 2. Blewah & 74 \\
\hline & $\begin{array}{l}3 . \\
\text { Kolang- } \\
\text { kaling }\end{array}$ & 52 \\
\hline & 4. Kelapa & 70 \\
\hline & 5. Kopi & 43 \\
\hline \multicolumn{2}{|l|}{ Jumlah total } & 301 \\
\hline \multicolumn{2}{|c|}{ Rata-rata per kategori (301: 5) } & 60.5 \\
\hline
\end{tabular}

Pada kategori 5 dan 6, terlihat bahwa variabel 'berasal' dari bunga dihilangkan, dan ini memperlihatkan perbedaan yang sangat signifikan dengan ketika variabel tersebut dipertahankan. Sebagian responden merasa ragu dengan apakah bengkoang dianggap sebagai buah atau bukan. Nilai yang diperoleh bengkoang adalah 68 dari 100 poin. Ini menunjukkan bahwa waktu santap, cara santap, dan fungsi menjadikannya dikategorikan sebagai buah oleh masyarakat Indonesia. Pada brokoli, brokoli lebih berfungsi sebagai sayur dan tidak dapat dimakan mentah. Pada tebu, hal yang membedakannya dengan bengkoang adalah tekturnya dan bentuknya yang masih menyerupai batang, sehingga tebu tidak begitu diterima sebagai buah, walaupun pada beberapa responden dari suku Jawa (tidak semua) menilai ragu-ragu dan ada yang menjadikannya sebagai buah.

Pada hasil penemuan ini ditunjukkan bahwa buah yang bukan merupakan hasil perkembangan dari bakal buah (dari bunga) ternyata disebut juga sebagai 'buah' dalam masyarakat. Buah yang merupakan hasil perkembangan bukan dari bunga, yang kemudian digolongkan sebagai 'buah' adalah seperti bengkoang Pada data tentang bengkoang, sebagian responden menjawab bahwa bengkoang termasuk dalam kategori buah, padahal bengkoang merupakan akar atau umbi yang membesar. Menurut temuan penulis, bengkoang dikategorikan sebagai buah karena daging buahnya yang berair, berasa manis, dan dapat dimakan tanpa proses memasak terlebih dahulu. Hal yang membedakan antara bengkoang 
dan umbi lain semacam ubi jalar adalah ubi jalar memerlukan proses pemasakan sebelum disantap, misalnya direbus atau digoreng. Dari hasil pengamatan ini, hal yang jelas membedakan atara 'buah' dan 'bukan buah' dalam masyarakat Indonesia adalah apakah 'buah' tersebut memerlukan proses pemasakan sebelum disantap.

\begin{tabular}{|l|l|l|}
\hline $\begin{array}{l}\text { Nomor Kategori Per } \\
\text { Variabel }\end{array}$ & $\begin{array}{l}\text { Nama } \\
\text { Buah }\end{array}$ & Jumlah \\
\hline Kategori 5 & $\begin{array}{l}\text { 1. } \\
\text { Bengko } \\
\text { ang }\end{array}$ & 68 \\
\hline $\begin{array}{l}\text { Variabel: } \\
\begin{array}{l}\text { 2. Berwarna cerah } \\
\text { 3. daging buah berair } \\
\text { dan manis } \\
\text { 4. dimakan tanpa } \\
\text { melalui pemasakan. }\end{array}\end{array}$ & 2. Tebu & 42 \\
Jumlah total & \\
\hline $\begin{array}{l}\text { Rata-rata per kategori (110: } \\
\text { 2) }\end{array}$ & 55 \\
\hline
\end{tabular}

Memiliki rasa manis dan bisa dimakan dengan atau tanpa proses memasak menjadikan pisang kapok sebagai 'buah' dengan nilai 85 . Pada beberapa budaya di Indonesia, pisang kapok dapat disajikan dengan digoreng, direbus, ataupun dimakan langsung tanpa pengolahan lebih lanjut inilah yang membedakannya dengan cokelat yang walaupun memiliki variabel yang sama, namun

memiliki hasil penilaian yang berbeda.

\begin{tabular}{|l|l|l|}
\hline $\begin{array}{l}\text { Nomor Kategori Per } \\
\text { Variabel }\end{array}$ & Nama Buah & $\begin{array}{l}\text { Ju } \\
\text { mla } \\
\text { h }\end{array}$ \\
\hline Kategori 7 & $\begin{array}{l}\text { 1. Pisang } \\
\text { Kapok }\end{array}$ & 85 \\
\hline $\begin{array}{l}\text { Variabel: } \\
\text { 2. Berwarna cerah } \\
\text { 3. daging buah berair } \\
\text { dan manis } \\
\text { 5. berasal dari bunga. }\end{array}$ & 6 Cokelat & 55 \\
\hline Jumlah total & 140 \\
\hline Rata-rata & 70 \\
\hline \multicolumn{3}{|c|}{ Variabel 'daging buah yang berair } \\
dan manis' serta 'disantap tanpa \\
melalui proses pemasakan' dilakukan \\
pada kategori 8 dan sukunlah yang \\
dijadikan sebagai sampel buah, dan \\
hasil menunjukkan bahwa rasa dan \\
cara santap berpengaruh terhadap \\
pengklasifikasian buah di Indonesia.
\end{tabular}

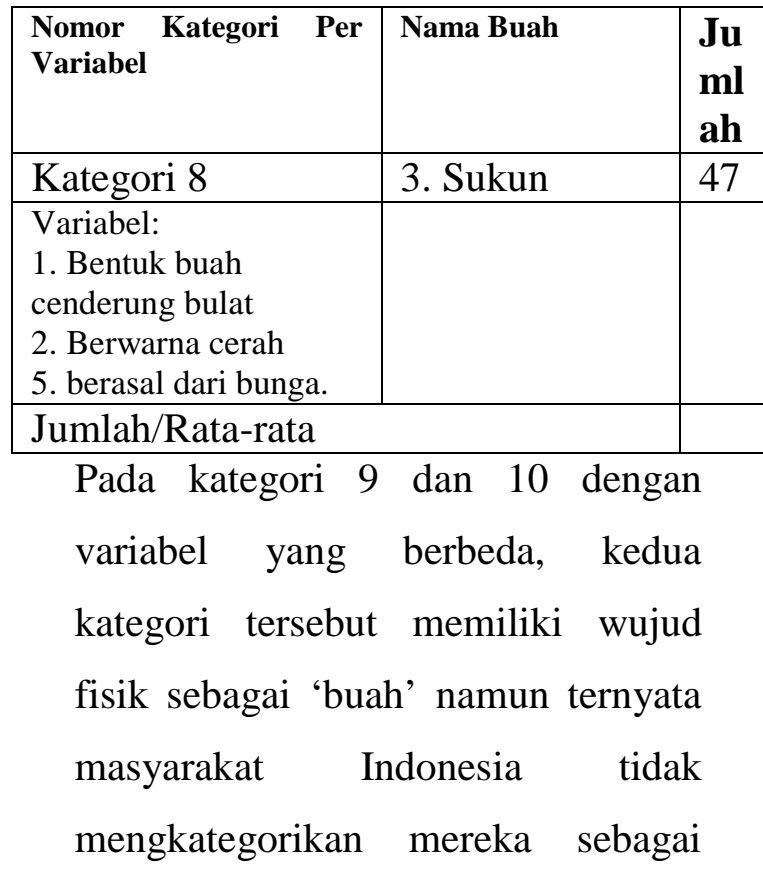


‘buah' karena variabel rasa dan cara santap yang mengharuskan sebagian dari data tersebut dimasak terlebih dahulu. Ini juga menunjukkan bahwa adanya variabel baru yang muncul yaitu 'fungsi' dalam masyarakat. 'Fungsi' dapat membantu kognitif manusia mengkategorikan 'buah' atau bukan.

\begin{tabular}{|l|l|l|}
\hline $\begin{array}{l}\text { Nomor Kategori Per } \\
\text { Variabel }\end{array}$ & Nama Buah & $\begin{array}{c}\text { Ju } \\
\text { ml } \\
\text { ah }\end{array}$ \\
\hline Kategori 9 & 2. Timun & 49 \\
\hline Variabel: & & \\
2. Berwarna cerah & & \\
4. dimakan tanpa \\
melalui pemasakan. \\
5. berasal dari bunga. & & \\
\hline Jumlah/Rata-rata & & \\
\hline
\end{tabular}

\begin{tabular}{|l|l|l|}
\hline $\begin{array}{l}\text { Nomor Kategori Per } \\
\text { Variabel }\end{array}$ & Nama Buah & $\begin{array}{l}\text { Juml } \\
\text { ah }\end{array}$ \\
\hline Kategori 10 & $\begin{array}{l}\text { 1. } \\
\text { Belimbin } \\
\text { g Wuluh }\end{array}$ & 63 \\
\hline $\begin{array}{l}\text { Variabel: } \\
\text { 2. Berwarna cerah } \\
\text { 5. berasal dari bunga. }\end{array}$ & 3. Terong & 28 \\
\cline { 2 - 3 } & 4. Pare & 25 \\
\cline { 2 - 3 } & 5. Petai & 26 \\
\cline { 2 - 3 } & 6. Lotus & 24 \\
\cline { 2 - 3 } & $\begin{array}{l}\text { 7. } \\
\text { Melinjo }\end{array}$ & 44 \\
\hline \multicolumn{2}{|l|}{ Jumlah total } & 210 \\
\hline $\begin{array}{l}\text { Rata-rata per kategori (210 : } \\
\text { 7) }\end{array}$ & 30 \\
\hline
\end{tabular}

Data pada kategori 11 adalah data yang mencoba membuktikan bahwa satu variabel dapat diberlakukan pada penelitian ini arau tidak.
Namun, hal yang jelas terbukti bahwa sangat sulit mencari contoh data dengan variabel saja, dan hasil yang dapat diprediksi bahwa satu variabel akan memperendah status ke'buah' an suatu data.

\begin{tabular}{|l|l|l|}
\hline $\begin{array}{l}\text { Nomor Kategori Per } \\
\text { Variabel }\end{array}$ & Nama Buah & $\begin{array}{l}\text { Jum } \\
\text { lah }\end{array}$ \\
\hline Kategori 11 & 1. Talas & 33 \\
\hline $\begin{array}{l}\text { Variabel: } \\
\text { 3. daging buah berair } \\
\text { dan manis }\end{array}$ & 2. Rebung & 20 \\
\hline Jumlah total & 53 \\
\hline Rata-rata per kategori & 26,5 \\
\hline
\end{tabular}

Pada simpulan akhir, penulis membedakan 'buah' yang didefinisikan secara botani dan 'buah' yang disebut sebagai buah dalam sudut pandang masyarakat Indonesia. Buah-buah itu sedemikian beragam, sehingga sukarlah rasanya untuk menyusun suatu skema pengelompokan yang dapat mencakup semua macam buah yang telah dikenal orang. Pada akhirnya peneasyarakat Indonesia juga mengelompokkan buah berdasarkan fungsi, bentuk, rasa, dan waktu santap.

\section{KESIMPULAN DAN SARAN}

Berdasarkan hasil yang diperoleh dari LP1, LP2, dan LP3, maka proses penarikan kesimpulan 
dapat dilakukan. Pemilihan contoh baik atau prototipe 'buah' dilakukan dengan memilih buah tertentu yang dapat merepresentasikan 'buah’ yang baik sebagai contoh dalam masyarakat bahasa Indonesia. Apel dan jeruk dipilih sebagai contoh yang baik karena kebanyakan dari responden menggambar dan menjawab apel dan jeruk sebagai contoh buah yang baik.

Pada kasus tomat, tomat memiliki variabel yang sama dengan apel yaitu bentuknya bulat, berwarna cerah, daging buah berair dan manis, keduanya berasal dari bunga, dan keduanya dapat dinikmati tanpa proses memasak lebih lanjut. Namun, hasil menunjukkan sesuatu yang berbeda, apel dianggap sebagai contoh buah yang baik sementara tomat tidak. Ini dikarenakan fungsi 'buah' tersebut dalam masyarakat. Apel lebih sering dikonsumsi oleh masyarakat Indonesia sebagai makanan pencuci mulut, sementara tomat lebih sering dimanfaatkan sebagai pelengkap masakan, oleh karena itulah tomat lebih sering dikategorikan sebagai sayur dibandingkan sebagai buah.
Munculnya variabel baru yang hadir ketika penelitian ini sedang dijalankan adalah 'fungsi atau kedudukan 'buah' dalam masyarakat' dapat dijadikan sebagai variabel yang disarankan oleh penulis untuk penelitian-penelitian tentang melihat pengkategorian dan mencari prototipe tumbuhan, khususnya buah.

\section{DAFTAR PUSTAKA}

Berger, Bruce. n.d . Persuasive Communication Part I. New York : U.S. Pharmacist a Jobson Publication.

Lewis, Robert A. 2002. CRC Dictionary of Agricultural Sciences. CRC Press.

Tjitrosoepomo, Gembong. 1986. Morfologi Tumbuhan. Jogjakarta. Gajah Mada University.

Sternberg, R.J. 2006. Cognitive Psychology. Belmont : CA Thomson Wadsworth

Smith, Edward E. 1988. Combining Prototypes: A Selective Modification Model dalam Cognitive Science 12, 485527. Michigan : University of Michigan.

Wierzbicka, Anna. 1992. Semantics. Culture, and Cognition: Universal Human Conceps in CultureSpecific Configurations. Oxford : Oxford University Press. 